\title{
Human Cathelicidin in Tinea Versicolor and Tinea Circinata
}

\author{
AMR A. RATEB, M.D.*; AMIRA M. EL TAWDY, M.D.*; FAISAL NOUR EL DIN, M.D.**; \\ RANA ABD ELAZEEM HAMMAD, M.Sc.**; KHALDA S. MOHAMED, M.D.*** and \\ DINA M. SALAMA, M.D.*
}

The Department of Dermatology, Faculty of Medicine, Cairo University* and National Research Center** and Molecular Genetics Department, National Research Center***

\begin{abstract}
Background: Fungal skin infections such as superficial tinea and pityriasis versicolor are very common and affect people all over the world. Recent research suggests that certain antimicrobial peptides can also play a role in the body's natural defense against fungal infection.

Aim of Study: The aim of this research is to look at the tissue expression of Cathelicidin mRNA in tinea versicolor and tinea circinata skin lesions to learn more about its function in fungal infection pathogenesis.

Patients and Methods: Twenty patients with tinea versicolor, twenty with tinea circinata, and twenty controls participated in this case-control study. A punch skin biopsy was obtained from the patient's lesional and non-lesional skin, as well as the control's normal skin, for real time PCR (RT-PCR) gene expression of cathelicidin mRNA.

Results: Cathelicidin was upregulated in lesional areas of tinea versicolor and tinea circinata in comparison to non lesional areas of tinea versicolor, tinea circinata and control. These results reached a statistical significance for mRNA cathelicidin in both diseases ( $p$-value $<0.001$ )
\end{abstract}

Conclusion: The results back up the theory that antimicrobial peptides like Cathelicidin can help defend the skin from dermatophytes and M.furfur.

Key Words: Cathelicidin - Tinea circinata - Tinea versicolor.

\section{Introduction}

IN all modes of life, antimicrobial peptides (AMPs), also known as host defense peptides (HDPs), are a significant component of the innate immune response. Such peptides are strong, broad-spectrum antibiotics with a lot of potential as new therapeutic agents. Gram-positive and Gram-negative bacteria, enveloped viruses, fungi, transformed and/or cancerous cells have all been shown to be killed by antimicrobial peptides [1].

Correspondence to: Dr. Amr A. Rateb, The Department of Dermatology, Faculty of Medicine, Cairo University
Cathelicidins are a family of antimicrobial peptides; only one cathelicidin, LL37, has been identified in humans. This peptide is found in White blood cells (WBCs), neutrophils, monocytes, Natural killer cells, T cells, and B cells, as well as epithelial cells of the testis, skin, gastrointestinal, and respiratory tracts, and is extracted by proteolysis from the C-terminal end of the human CAP 18 protein (hCAP18) [2]. Inflammatory or infectious stimuli induce LL37, which has antimicrobial activity toward Gram-negative and Gram-positive bacteria. In a septicemia murine model, the peptide binds and neutralizes LPS and defends toward endotoxic shock, in addition to antimicrobial activity [3].

Cathelicidin production increases adaptively in response to a variety of particular infections as well as any acute epithelial barrier damage. Cathelicidin production is also linked to a few chronic inflammatory disorders, indicating cathelicidins' dual roles in immune activation [4] .

The aim of this research is to look into the tissue expression of Cathelicidin mRNA in tinea versicolor and tinea circinata lesions, in order to better study its function in fungal infection pathogenesis.

\section{Patients and Methods}

During 2017, patients with tinea versicolor and tinea circinata who visited the Dermatology outpatient clinic at Cairo University's Kasr El Eini Faculty of Medicine were studied. The study included forty patients of tinea versicolor and tinea circinata [ 20 patients diagnosed with tinea versicolor and 20 patients diagnosed with tinea circinata (twenty males and twenty females)] their ages varied from 16 to 38 years old, with the average 
being 25. Diagnosis was made on clinical basis was done, and also the study included 20 control (healthy individuals suffering from hair fall). After the Dermatology Research Ethical Committee Office, Faculty of Medicine, Cairo University, and the National Research Center Ethical Committee approved the study, all patients and controls signed written informed consents.

Cases were selected from the Dermatology outpatient clinic according to the following criteria including all ages, sexes, whatever first attack or recurrent attack. No associated diseases were found among the patients group.

Patients were subjected to full medical history including personal, present (onset, course and duration) as well as past and family history.

\section{Tissue sample collection and RNA extraction:}

Two skin biopsies ( $5 \mathrm{~mm}$ punch) were taken from every patient (a lesional biopsy and non lesional one). One skin biopsy was taken from control. Sterilization of Skin surface using alcohol swabs and anaesthetized with $2 \%$ lidocaine was done. For the punch biopsy, the tool was pushed $5 \mathrm{~mm}$ perpendicularly into the skin, rotated in a clockwise direction. Over the wound, a bandage was put on. All patients were advised to keep changing their bandages on a regular basis until the wound healed completely, and they were also instructed to use topical and systemic antibiotics (only if needed).

The biopsies were subjected to molecular analysis by RNA extraction of Cathelicidin genes then amplification of Cathelicidin gene by real time 'quantitative' polymerase chain reaction (PCR).

Total RNA has been extracted utilizing Trizol according to the manufacturer's instructions to identify mRNA expression (Applied BioSystems). cDNA was carried out in a total volume 20 [ 5 LART reaction, 10 Than universal PCR master mix (10 M) 1 foward primer (10 M) $1 \boldsymbol{L}$ reverse primer $(10 \mathrm{M})$ and $14.84 \boldsymbol{J}$ distilled water made up the total PCR volume of 25 The following were the PCR cycling conditions: denaturing at $94^{\circ} \mathrm{C}$ for 20 seconds, annealing at $56^{\circ} \mathrm{C}$ for 20 seconds, extension at $72^{\circ} \mathrm{C}$ for 30 seconds, and $80^{\circ} \mathrm{C}$ for 20 seconds. The primers were as follows:

GAPDH (141 pb): sense, 5'-CCTCAAGATCATCAGCAAT-3'; antisense, 5'CCATCCAGTCTTCTTCTGGGT-3'; probe,

\section{5'-FAM-ACCACAGTCCCATGCCAT- CATCAC-FAM-3'}

\section{Statistical analysis:}

When applicable, data were statistically defined using range, mean \pm standard deviation $( \pm S D)$, median, frequencies (number of instances), and percentages. The Anova test for independent samples was used to compare quantitative variables among the two research groups. Wilcoxon Signed Ranks test was used to compare categorical results. The Pearson correlation coefficient test was used to determine the relationship among different variables. A statistically significant $p$-value was less than 0.05. Microsoft Excel 2007 (Microsoft Corporation, NY, and USA) and SPSS (Statistical Package for the Social Science; SPSS Inc., Chicago, IL, USA) version 15 for Microsoft Windows were used to perform all statistical calculations.

\section{Results}

This research included forty patients (20 patients with tinea versicolor and 20 patients with tinea circinata). The patient group included 20 men (50\%) and 20 women $(50 \%)$. Their ages varied from 16 to 38 years old, with an average of $24.93 \pm 6.635$ years, with duration from 7 days to 3 months.

On comparing the level of expression of mRNA cathelicidin lesional and non lesional in both tinea versicolor and tinea circinata patients, a significant statistical difference was reported (higher in lesional areas). ( $p$-value $<0.001$ ) (Table $1 \&$ Fig. 1 ).

Table (1): Comparison between Cathelicidin mRNA expression lesional and non lesional in tinea versicolor and tinea circinata.

\begin{tabular}{|c|c|c|c|}
\hline & $\begin{array}{l}\text { Cathelicidin } \\
\text { lesional }\end{array}$ & $\begin{array}{l}\text { Cathelicidin } \\
\text { non-lesional }\end{array}$ & $\begin{array}{c}p- \\
\text { value }\end{array}$ \\
\hline Tinea versicolor & $\begin{array}{l}\text { Range: } 2.83-6.37 \\
\text { Mean } \pm S D: \\
4.7470 \pm 0.97979\end{array}$ & $\begin{array}{l}\text { Range: } 0.3-2.3 \\
\text { Mean } \pm \text { SD: } \\
1.474 \pm 0.6146\end{array}$ & $<0.001$ \\
\hline Tinea circinata & $\begin{array}{l}\text { Range: } 0.80-6.82 \\
\text { Mean } \pm \text { SD: } \\
3.7110 \pm 1.54165\end{array}$ & $\begin{array}{l}\text { Range: } 0.2-2.1 \\
\text { Mean } \pm S D: \\
1.108 \pm 0.6073\end{array}$ & $<0.001$ \\
\hline
\end{tabular}

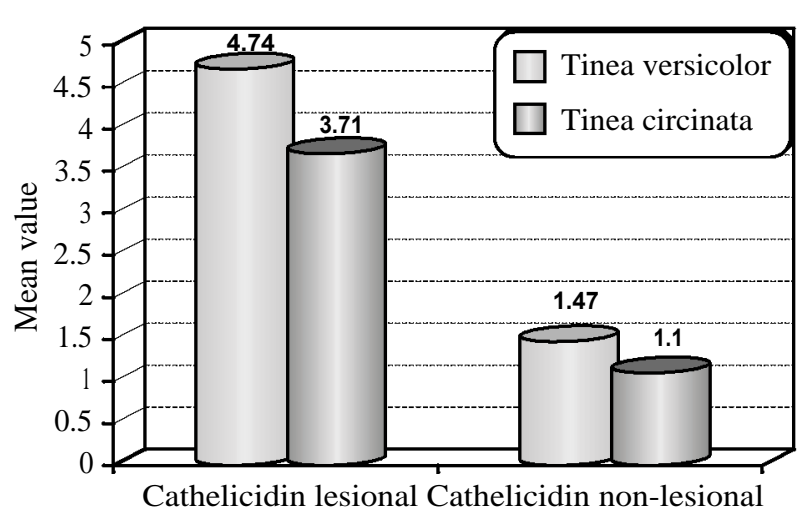

Fig. (1): Comparison between Cathelicidin mRNA expression lesional and non lesional in tinea versicolor and tinea circinata. 
Table (2): Comparison between Cathelicidin mRNA expression lesional tinea versicolor and tinea circinata and control group.

\begin{tabular}{llll}
\hline & \multicolumn{1}{c}{$\begin{array}{c}\text { Cathelicidin } \\
\text { lesional }\end{array}$} & \multicolumn{1}{c}{ Control } & $\begin{array}{c}p- \\
\text { value }\end{array}$ \\
\hline Tinea & Range: $2.83-6.37$ & Range: 0.3 8-2.94 & $<0.001$ \\
versicolor & Mean \pm SD: & Mean \pm SD: & \\
& $4.7470 \pm 0.97979$ & $1.1025 \pm 0.57774$ & \\
Tinea & Range: $0.80-6.82$ & Range: 0.3 8-2.94 & $<0.001$ \\
circinata & Mean \pm SD: & Mean \pm SD: & \\
& $3.7110 \pm 1.54165$ & $1.1025 \pm 0.57774$ & \\
\hline
\end{tabular}

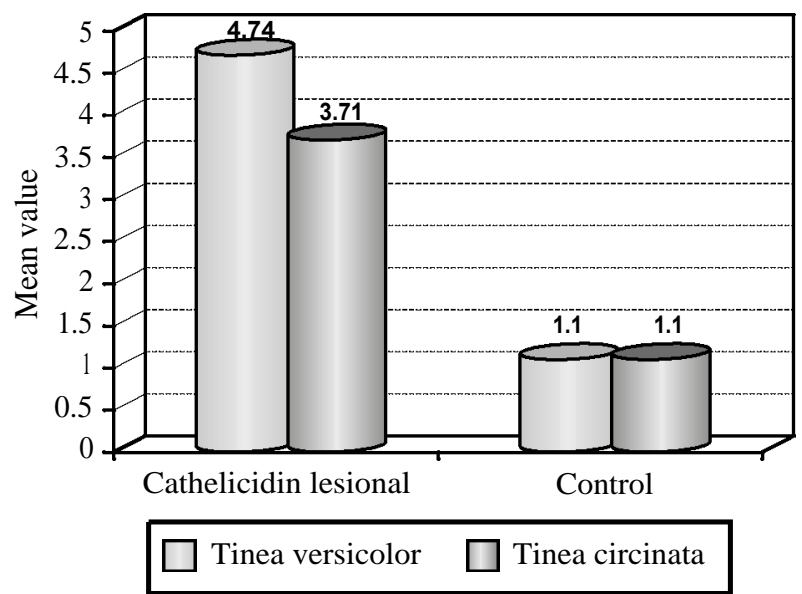

Fig. (2): Comparison between Cathelicidin mRNA expression lesional tinea versicolor and tinea circinata and control group.

A significant difference in the level of cathelicidin mRNA was detected in both tinea versicolor and tinea circinata compared to the control group, where lesional areas were much higher. ( $p$-value $<0.001$ ) (Table $2 \&$ Fig. 2).

No statistically significant correlation among tinea versicolor and tinea circinata patients was detected regarding age, duration of disease and recurrence rate with cathelicidin mRNA expression $(p>0.05)$

\section{Discussion}

Fungal skin infections such as superficial tinea and pityriasis versicolor are very common and affect people all over the world. The causative dermatophytes and Malassezia spp. spread through the epidermis' stratum corneum in the majority of cases. A moderate inflammatory response is often seen during infection. That response is characterized by a mild dermal infiltration of mononuclear cells and polymorphous leucocytes. Skin-invading fungi are usually restricted to the stratum corneum, despite the fact that only a small percentage of such inflammatory cells enter the superficial skin layers. This indicates that the skin may harbor natural non-cellular components against fungi [610].

Recent research suggests that certain antimicrobial peptides can play a role in the body's natural defense against fungal infection $[\mathbf{8 , 9 , 1 0 ]}$.

The ability of epithelia and granulocytes to produce antimicrobial molecules places them in a unique place to defend strongly against normally non-invasive organisms such as dermatophytes. Despite the fact that they are frequently infected by people who seem to have normal immune systems, the reason of this deficiency in such patients that makes them vulnerable to infection is unclear. [11] .

However, the function of naturally occurring antimicrobial peptides in fungal infection defense is unknown. Two major antimicrobial peptides were extensively studied in human skin: $\beta$-defensins and cathelicidins [12]

Skin as well as other epithelial surfaces are significant producers of functional cathelicidins, and their expression is affected by them $[\mathbf{1 3 , 1 4 , 1 5}]$

Locations of many cationic peptides such as cathelicidins and regulation of expression of them have suggested their role as the first line of immune defense against skin pathogens [16]

The objective of this research is to investigate the possible role of AMPs (cathelicidin) for defending against cutaneous fungal diseases.

Expression of cathelicidin was assessed (by RT-PCR) in lesional and non lesional areas in patients having tinea versicolor and others having tinea circinata and in 20 healthy control subjects.

Out of the forty patients involved in the study a statistical significant increase of the level of cathelicidin was reported in all patients (in lesional areas) compared to the control group (in 20 individuals).

This result was consistent with the findings of López-García et al., López-García et al., Brasch et al., $[12,17,18]$. Similar results have been reported with them but mostly using immunostaining of skin biopsies. They revealed a significant increased expression of AMPs (cathelicidin) in the distinct layers of lesional epidermis when compared to the control group.

Again the significant statistical reported differences for AMPs in this current study between 
lesional and that of the non lesional areas in the same patient being higher in lesional areas assures more that AMPs (cathelicidin) resemble an integral part of the innate immunity expressed in a specific form in skin areas only where the fungus resides causing the resultant pathology.

Dermatophytes and yeast are two different forms of fungal organisms causing tinea circinata and tinea versicolor respectively. Hence we investigated the expression of AMPs in both diseases to elaborate any possible difference in the immunogenic reaction related to the type of the fungal organism.

Recurrence is a usual feature encountered in patients suffering from fungal infection especially seen in tinea versicolor patients.

Cathelicidin level showed no marked differences between both sexes.

In conclusion, the current study revealed significant higher levels of mRNA of cathelicidin in tinea versicolor and tinea circinata patients, highlighting its importance as an integral part of innate immunity to defense against superficial fungal infection. This hypothesis proposes new therapeutic paths and methods to a better understanding of each person's susceptibility to such specific dermatologic diseases.

\section{References}

1- REDDY K.V., YEDERY R.D. and ARANHA C.: "Antimicrobial peptides: Premises and promises". International Journal of Antimicrobial Agents, 24 (6): 536547, 2004.

2- GUDMUNDSSON G.H., AGERBERTH B., ODEBERG J., BERGMAN T., OLSSON B., et al.: The human gene FALL39 and processing of the cathelin precursor to the antibacterial peptide LL) 37 in granulocytes. Eur. J. Biochem., 238: 325-332, 1996.

3- AGERBERTH B., CHARO J., WERR J., OLSSON B., IDALI F., et al.: The human antimicrobial and chemotactic peptides LL) 37 and alpha-defensins are expressed by specific lymphocyte and monocyte populations. Blood, 96: 3086-3093, 2000.

4- GALLO R.L., MURAKAMI M., OHTAKE T. and ZAIOU M.: Biology and clinical relevance of naturally occurring antimicrobial peptides. J. Allergy Clin. Immunol., 110: 823-31, 2002

5- KEYS D.N., AU-YOUNG J.K. and FEKETE R.A.: Taq-
Man Array Cards in pharmaceutical research. Methods Mol. Biol., 632: 87-98, 2010.

6- AKIRA S.: Toll-like receptor signaling. J. Biol. Chem., 278: 38105-8, 2003.

7- SAWAMURA D., GOTO M., SHIBAKI A., et al.: Beta defensin-3 engineered epidermis shows highly protective effect for bacterial infection. Gene Ther., 12: 857-61, 2005 .

8- De JONGH G.J., ZEEUWEN P.L.J.M., KUCHAREKOVA M., et al.: High expression lev Gudmundsson els of keratinocyte antimicrobial proteins in psoriasis compared with atopic dermatitis. J. Invest Dermatol., 125: 1163 73, 2005.

9- ZHENG Y., NIYONSABA F., USHIO H., et al.: Microbicidal protein psoriasin is a multifunctional modulator of neutrophil activation. Immunology, 124: 357-67, 2008.

10-ZANGER P., HOLZER J., SCHLEUCHER R., STEFFEN H., SCHITTEK B., et al.: Constitutive expression of the antimicrobial peptide RNase 7 is associated with Staphylococcus aureus infection of the skin. J. Infect Dis., 200: 1907-15, 2009.

11- ALY R.: Ecology and epidemiology of dermatophyte infections. J. Am. Acad. Dermatol., 31: S21-5, 1994.

12- LÓPEZ-GARCÍA B., LEE P.H., YAMASAKI K. and GALLO R.L.: Anti-fungal activity of cathelicidins and their potential role in Candida albicans skin infection. J. Invest Dermatol., 125: 108-15, 2005.

13- BALS R., WANG X., ZASLOFF M. and WILSON J.M.: The peptide antibiotic LL-37/hCAP-18 is expressed in epithelia of the human lung where it has broad antimicrobial activity at the airway surface. Proc. Natl. Acad. Sci. USA, 95: 9541-9546, 1998.

14- FROHM M., AGERBERTH B., AHANGARI G., STAHLE-BACKDAHL M., LIDEN S., WIGZELL H., et al.: The expression of the gene coding for the antibacterial peptide LL-37 is induced in human keratinocytes during inflammatory disorders. J. Biol. Chem., 272: 15258-63, 1997.

15- GALLO L.R. and HUTTNER M.K.: Antimicrobial Peptides: An Emerging Concept in Cutaneous Biology. J. Invest Dermatol., 111: 739-743, 1998.

16- HOWELL M.D., JONES J.F., KISICH K.O., et al.: Selective killing of vaccinia virus by LL-37: Implications for eczema vaccinatum. J. Immunol., 172: 1763-7, 2004.

17- LÓPEZ-GARCÍA B., PHILLIP H.A. LEE and GALLO R.L.: Expression and potential function of cathelicidin antimicrobial peptides in dermatophytosis and tinea versicolor. Journal of antimicrobial Chemotherapy, 57: 877882,2006

18- BRASCH J., MÖRIG A., NEUMANN B. and PROKSCH E.: Expression of antimicrobial peptides and toll-like receptors is increased in tinea and pityriasis versicolor. Mycoses, 57: 147-152, 2014. 


\section{كاثيليثيدن فى عدوى الجلد الفطرية}

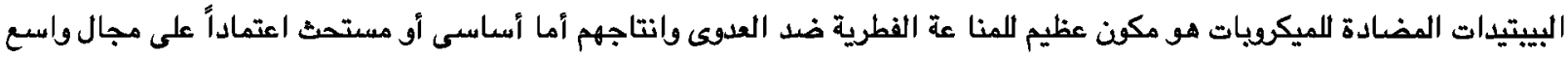

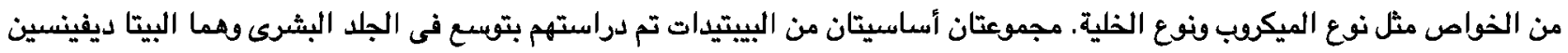

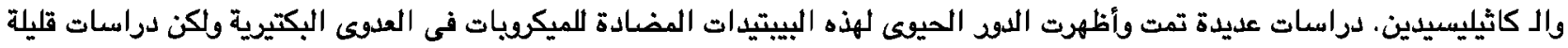
أقرث بخصوص العدوى الفطرية.

الهدف من هذه الدراسة: هو فحص التعبير الجينى النسيجى لكاثيشيثين في الجلد المصاب بالتينيا الملونة والتينيا الحلقية ومن ثم دراسة لدوهما في النشوء المرضى اللعدىى بالفطريات.

أظهرت هذه الدراسة فروق ذات دلالة إحصائية فى التعبير الجينى لهذه البيتيدات فى الجلد المصاب الجياب مقارنة بالجلد السليم (العينة الضابطة).

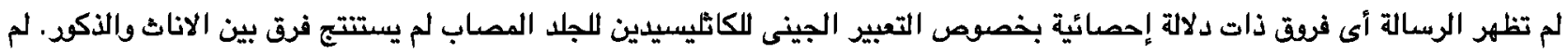

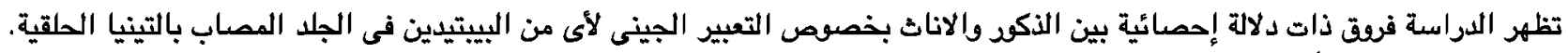

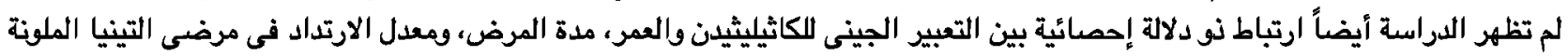
أو الحلقية.

وقجد أيضاً ارتفاع ذو دلالة إحصائية للتعبير الجينى للكاثيليشيدن فى الجلد المماب مقارنة بالجلد السليم مما يؤكد دودما فى الدفاع

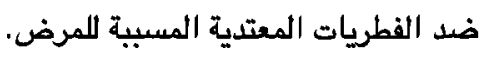

